\title{
Study on the Dynamic Recrystallization Behavior of 47Zr-45Ti-5Al-3V Alloy by CA-FE Simulation
}

\author{
Wenwei Zhang, Qiuyue Yang, Yuanbiao Tan*(D), Ya Yang *, Song Xiang (1) and Fei Zhao \\ Guizhou Key Laboratory of Materials Mechanical Behavior and Microstructure, College of Materials and \\ Metallurgy, Guizhou University, Guiyang 550025, China; Zww19960916@163.com (W.Z.); \\ yangqy979@126.com (Q.Y.); sxiang@gzu.edu.cn (S.X.); fzhao@gzu.edu.cn (F.Z.) \\ * Correspondence: ybtan1@gzu.edu.cn (Y.T.); yangyaing@126.com (Y.Y.); Tel.: +86-147-8515-8006 (Y.T.)
}

check for updates

Citation: Zhang, W.; Yang, Q.; Tan, Y.; Yang, Y.; Xiang, S.; Zhao, F. Study on the Dynamic Recrystallization Behavior of 47Zr-45Ti-5Al-3V Alloy by CA-FE Simulation. Materials 2021, 14, 2562. https://doi.org/10.3390/ ma14102562

Academic Editor: Ivo Schindler

Received: 17 April 2021

Accepted: 7 May 2021

Published: 14 May 2021

Publisher's Note: MDPI stays neutral with regard to jurisdictional claims in published maps and institutional affiliations.

Copyright: (C) 2021 by the authors Licensee MDPI, Basel, Switzerland. This article is an open access article distributed under the terms and conditions of the Creative Commons Attribution (CC BY) license (https:/ / creativecommons.org/licenses/by/ $4.0 /)$.

\begin{abstract}
The dynamic recrystallization (DRX) behavior of 47Zr-45Ti-5Al-3V alloy was studied by using the experiment and numerical simulation method based on DEFORM-3D software and cellular automata (CA) over a range of deformation temperatures $\left(850\right.$ to $\left.1050{ }^{\circ} \mathrm{C}\right)$ and strain rates $\left(10^{-3}\right.$ to $\left.10^{0} \mathrm{~s}^{-1}\right)$. The results reveal that the DRX behavior of 47Zr-45Ti-5Al-3V alloy strongly depends on hot-working parameters. With rising deformation temperature $(T)$ and decreasing strain rate $(\dot{\varepsilon})$, the grain size $\left(d_{D R X}\right)$ and volume fraction $\left(\mathrm{X}_{D R X}\right)$ of DRX dramatically boost. The kinetics models of the $d_{D R X}$ and $X_{D R X}$ of DRX grains were established. According to the developed kinetics models for DRX of $47 \mathrm{Zr}-45 \mathrm{Ti}-5 \mathrm{Al}-3 \mathrm{~V}$ alloy, the distributions of the $d_{D R X}$ and $\mathrm{X}_{D R X}$ for DRX grains were predicted by DEFORM-3D. DRX microstructure evolution is simulated by CA. The correlation of the kinetics model is verified by comparing the $d_{D R X}$ and $X_{D R X}$ between the experimental and finite element simulation (FEM) results. The nucleation and growth of dynamic recrystallization grains in 47Zr-45Ti-5Al-3V alloy during hot-working can be simulated accurately by CA simulation, comparing with FEM.
\end{abstract}

Keywords: 47Zr-45Ti-5Al-3V alloy; hot-working; DRX behavior; FEM; CA

\section{Introduction}

Zirconium alloys owns low thermal neutron absorption cross-section, superior mechanical properties for long term operations in high pressure and adequate corrosion resistance in contact with high-temperature water, which plays a significant role in structural materials of the aerospace field [1-3]. With the rapid development of the aviation industry, the increasing requirement in the mechanical properties was needed for the structural materials of the aerospace field. Recently, a series of new ZrTiAlV alloys with an ultrahigh strength were designed [4-9]. The mechanical properties of key components were depended on the microstructure produced during hot-working of the ZrTiAlV alloys, which was effected by hot processing parameters. Therefore, it is essential to deeply reveal the microstructure evolution and deformation mechanism of ZrTiAlV alloys at various hot-processing conditions. In the previous work, the hot-deformation behavior of ZrTiAlV alloys was investigated, and the constitutive equation and processing maps have established [7-11]. The hot-deformation behavior of new 47Zr-45Ti-5Al-3V alloy is significantly different from that of traditional zirconium alloys [12-15]. For the 47Zr-45Ti-5Al-3V alloy, the dynamic recrystallization is not easily occurred at low deformation temperature and high strain rate. Generally, DRX is regarded as an excellent way to refine the grain size of metals during the hot-working. However, no published investigation on the DRX kinetics behavior of $47 \mathrm{Zr}-45 \mathrm{Ti}-5 \mathrm{Al}-3 \mathrm{~V}$ alloys has been carried out. Thus, it is critical to understand the microstructure evolution in the process of DRX and construct the DRX kinetics model for improving the mechanical properties of 47Zr-45Ti-5Al-3V alloy.

Recently, with the rapid increase in computer performance, the DRX kinetics of metals during hot-working has been qualitatively studied by using the software of FEM and 
CA [16-24]. Irani et al. [16] investigated the DRX kinetics of the AA6060 aluminum alloy by the FEM method. The results demonstrated that controlling the number of element points can effectively improve efficiency and increase the accuracy of FEM. Ji et al. [17] embed the DRX kinetics model for 33Cr23Ni8Mn3N alloy into the DEFORM-3D software to characterize the relationship between hot-working parameters and the $d_{D R X}$ and $X_{D R X}$ of DRX grains. The result manifests a good consistent between the simulation and experimental results. Wu et al. [18] utilized a cellular automaton (CA) coupled with FEM by means of ABAQUS software to study the DRX microstructure evolution of AZ61 alloy. The simulation results correspond well to the experimental results. NithinBaler et al. [19] revealed the DRX mechanism of $\gamma^{\prime}$-L12 alloy by the FEM methods, which was discontinuous dynamic recrystallization (DDRX). Geng et al. [20] also reported that the DRX evolution of GH4169 superalloy during hot-working can be better predicted by FEM software integrated with the developed kinetics model. Zhang et al. [21] studied the microstructure evolution of 7055 aluminum alloy in the rolling process by using FEM and CA methods, and found that CA method can more accurately simulate the evolution of DRX. Li et al. [22] utilized the 3D-CA method to describe the DRX behavior and mechanical response of the titanium alloy during the uneven deformation, which showed a good consistency with the results obtained by experimental test. All in all, the CA and FEM methods have been widely regarded as valid ways to predict the microstructure evolution in the DRX process of metals and alloys.

In order to reveal the DRX behavior and construct the DRX kinetics model of $47 \mathrm{Zr}-45 \mathrm{Ti}$ 5Al-3V alloy, in this present work, the CA-FE method is used to study the DRX behavior of $47 \mathrm{Zr}-45 \mathrm{Ti}-5 \mathrm{Al}-3 \mathrm{~V}$ alloy from the macro- and micro-scales. A developed kinetics model of the DRX for 47Zr-45Ti-5Al-3V alloy was established. The microstructure evolution of the alloy in the process of DRX was analyzed by DEFORM-3D software and CA integrated with the developed kinetics and dislocation models. Additionally, a comparison of the difference between the experimental and simulated results has been carried out to testify the validity of FE-CA simulation.

\section{Experiment}

A forged 47Zr-45Ti-5Al-3V alloy (wt.\%) was employed in this work. The specific preparation process has been introduced in the previous work [8]. The phase transformation temperature of $\beta \rightarrow \alpha+\beta$ for $47 \mathrm{Zr}-45 \mathrm{Ti}-5 \mathrm{Al}-3 \mathrm{~V}$ alloy is $703^{\circ} \mathrm{C}$ [5]. The forged alloy was solution-treatment at $1050{ }^{\circ} \mathrm{C}$ for $0.5 \mathrm{~h}$ and subsequently water-quench. Figure 1a depicts the initial microstructure of the solution-treated alloy with an average grain size of about $450 \mu \mathrm{m}$.
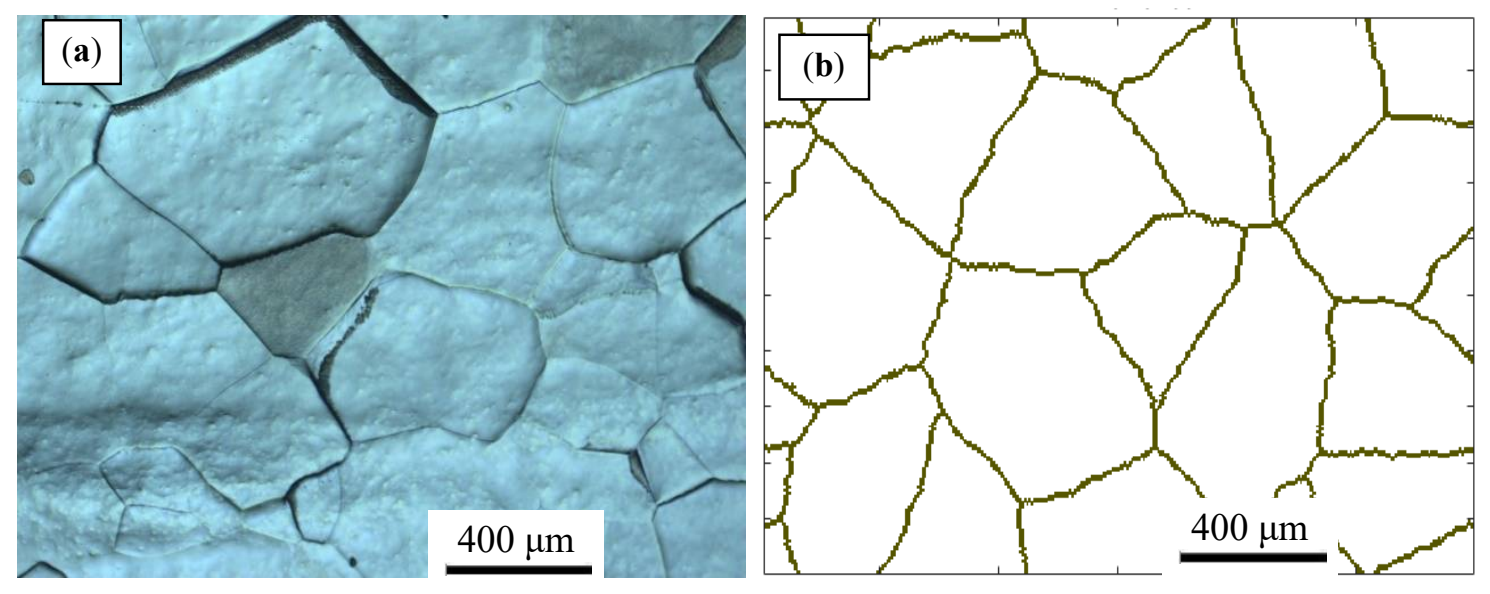

Figure 1. (a) Microstructure of the $47 \mathrm{Zr}-45 \mathrm{Ti}-5 \mathrm{Al}-3 \mathrm{~V}$ alloy solution-treatment at $1050^{\circ} \mathrm{C}$ for $0.5 \mathrm{~h}$. (b) Initial microstructure simulated by CA. 
Cylindrical samples of $\varnothing 8 \times 12 \mathrm{~mm}$ were prepared by the wire cutting. To analyze the DRX behavior and construct the DRX kinetics model of 47Zr-45Ti-5Al-3V alloy, hot compression test was conducted on a Gleeble 3500 at various testing conditions. The deformation temperature was set in the range of 850 to $1050{ }^{\circ} \mathrm{C}$, and the strain rate was set in the range of $10^{-3}$ to $10^{0} \mathrm{~s}^{-1}$. The schematic diagram of the experimental tests is shown in Figure 2. The testing samples were compressed to a true strain of 0.7 . For preserving the microstructure of the deformed samples, the deformed samples were rapidly water-quenched to $20^{\circ} \mathrm{C}$.

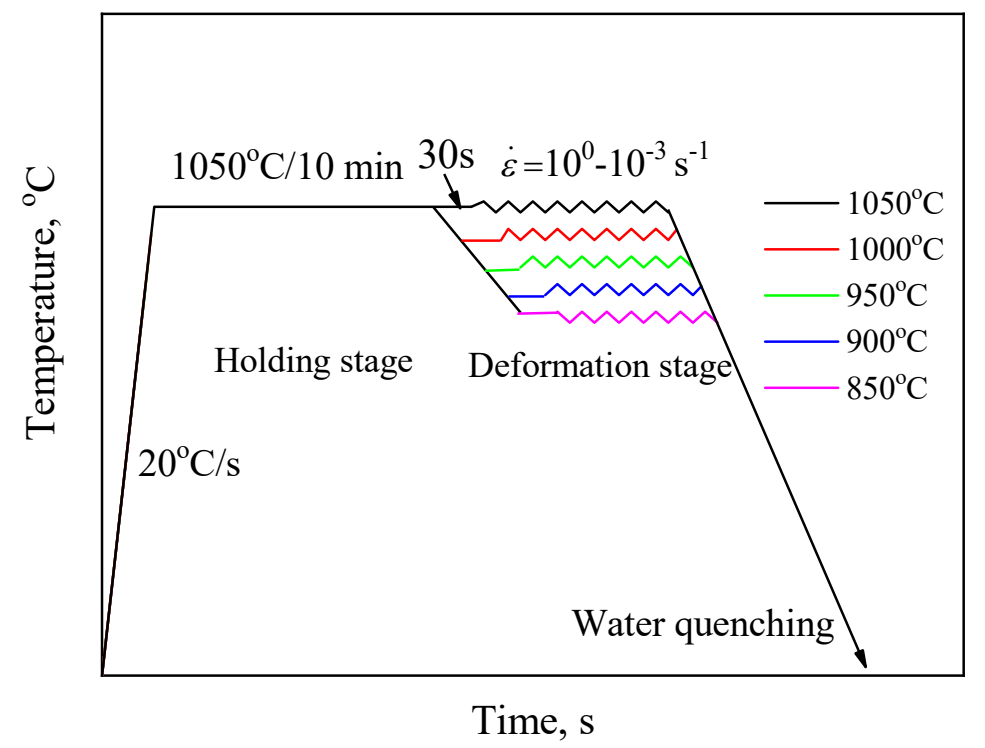

Figure 2. Schematic diagram of the experimental tests in this work.

For optical microstructure observation (OM) by using Leica DMI5000M, the deformed samples were ground and then etched by chemical means. The etching solution is a Kroll reagent of $15 \% \mathrm{HF}, 40 \% \mathrm{HNO}_{3}$ and $45 \% \mathrm{H}_{2} \mathrm{O}$ (Vol.\%). The value of the $d_{D R X}$ and $\mathrm{X}_{D R X}$ of DRX grains was counted by the Image-Pro software (Media Cybernetics, Silver Spring, MD, USA).

\section{Results and Discussion}

\subsection{Hot-Deformed Microstructure}

Figure 3 presents typical stress-strain curves for the ZrTiAlV alloy at different temperatures. It is seen that the stress-strain curves illustrate a dynamic recovery characteristic at a low deformation temperature and high strain rate, while showing a dynamic recrystallization characteristic at a high deformation temperature and low strain rate. Figure 4 displays the representative deformed microstructures of the $47 \mathrm{Zr}-45 \mathrm{Ti}-5 \mathrm{Al}-3 \mathrm{~V}$ alloy. At the strain rate of $1 \mathrm{~s}^{-1}$, the initial grains of the samples deformed at the temperatures of 850 and $900{ }^{\circ} \mathrm{C}$ were elongated perpendicular to the compression direction of deformed samples, indicating that only DRV occurred. When the samples deformed at $950{ }^{\circ} \mathrm{C} / 1 \mathrm{~s} \mathrm{~s}^{-1}$, a few fine grains of DRX formed at the grain boundaries of deformed grains, showing that dynamic recrystallization firstly took place under this deformation condition. As the deformation temperature increases and the $\dot{\varepsilon}$ decreases, the grain boundary migration rate is accelerated and the $X_{D R X}$ and $d_{D R X}$ of DRX grains increase. At the hot-working parameters of $1000{ }^{\circ} \mathrm{C}$ and $0.001 \mathrm{~s}^{-1}$, the microstructure with uniform equiaxed grains can be achieved, revealing that a full DRX occurred during hot-working. When the $T$ further raised to $1050{ }^{\circ} \mathrm{C}$, there were obvious coarsening for the DRX grains. It is attributed to a fact that high deformation temperature and low $\dot{\varepsilon}$ provide enough energy and sufficient time for dynamic recrystallization to nucleate and grow, so the dynamic recrystallization is more sufficient under this condition. 

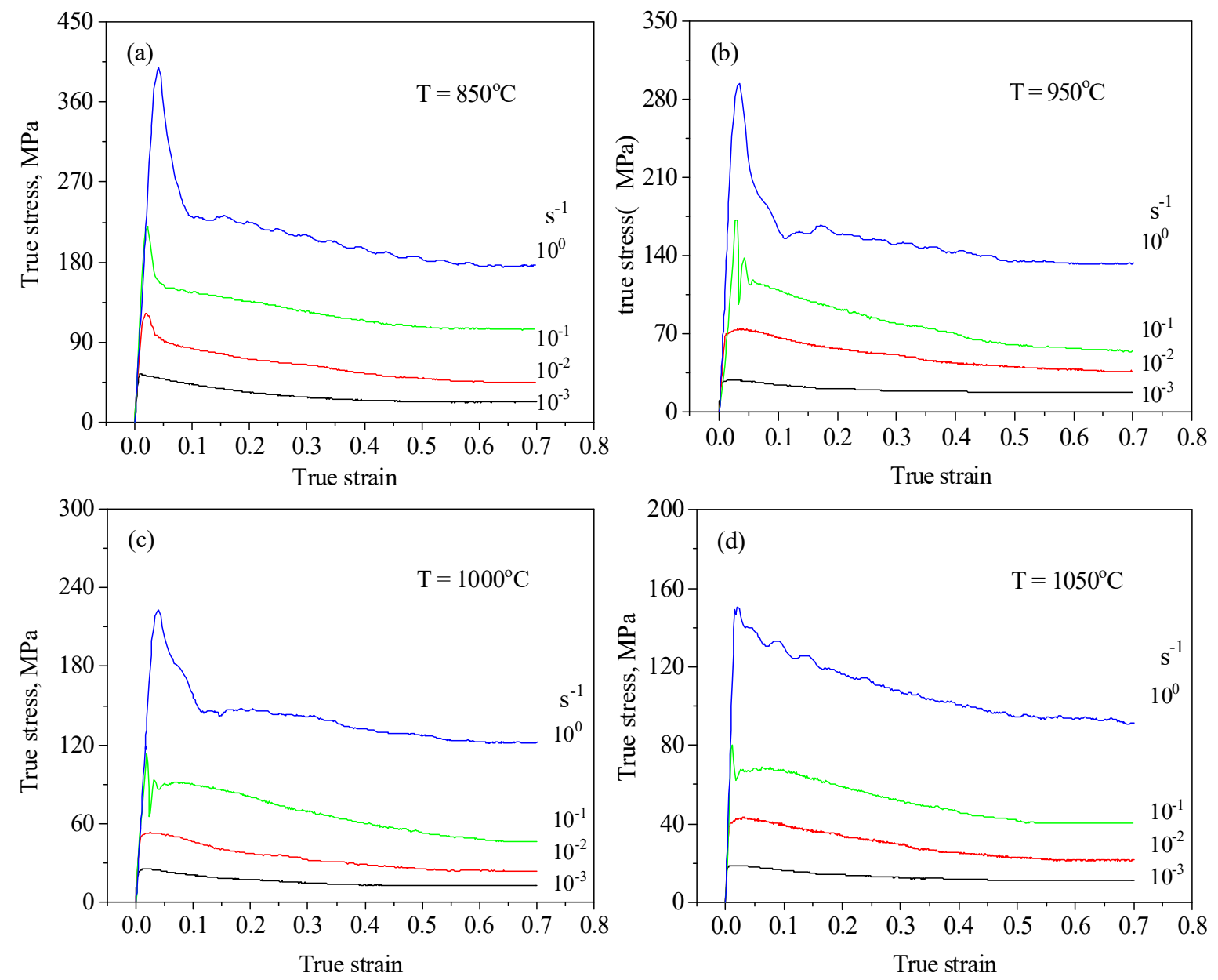

Figure 3. Typical stress-strain curves for the ZrTiAlV alloy at different temperatures [11]. (a) $\mathrm{T}=850{ }^{\circ} \mathrm{C} ;(\mathbf{b}) \mathrm{T}=950{ }^{\circ} \mathrm{C}$; (c) $\mathrm{T}=1000{ }^{\circ} \mathrm{C} ;(\mathbf{d}) \mathrm{T}=1050{ }^{\circ} \mathrm{C}$.
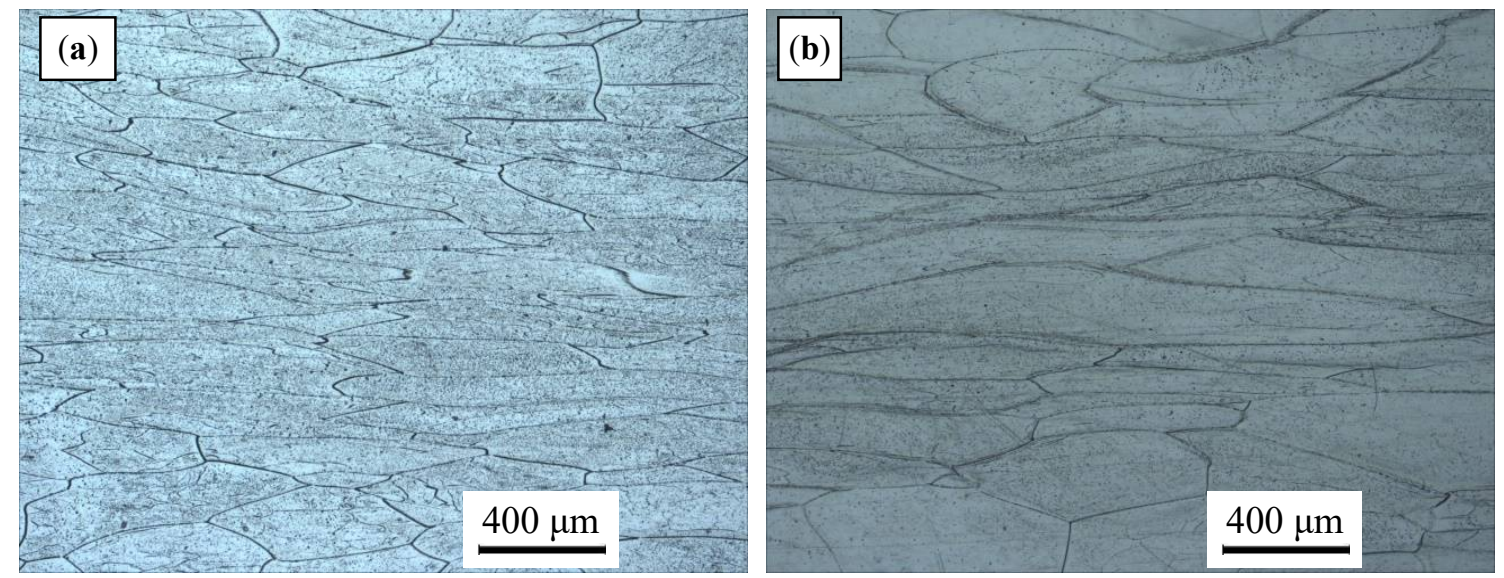

Figure 4. Cont. 

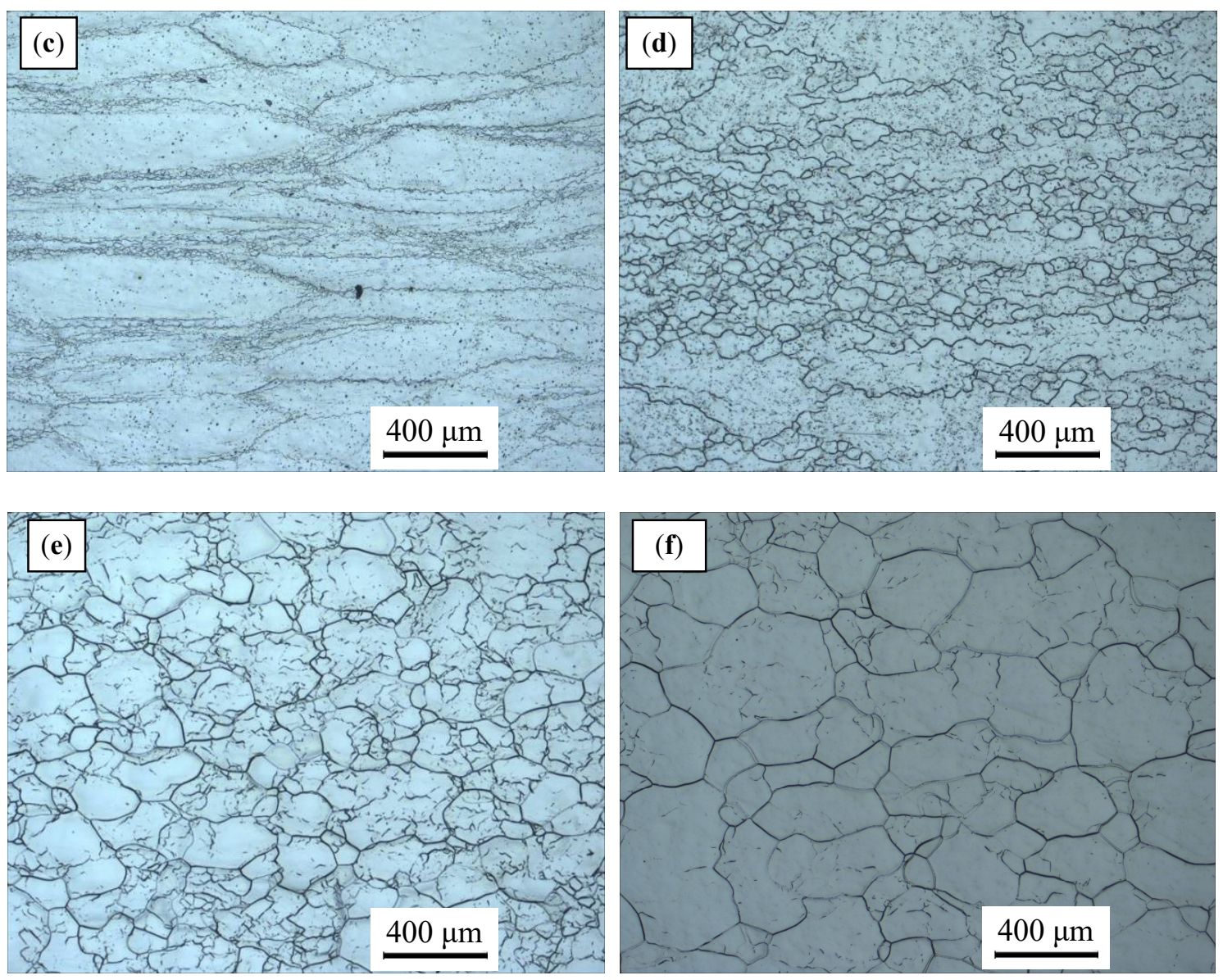

Figure 4. Optical microstructures of ZrTiAlV alloy under different hot-working conditions at the true strain of $0.7:\left(\right.$ a) $850{ }^{\circ} \mathrm{C}$, $1 \mathrm{~s}^{-1}$; (b) $900{ }^{\circ} \mathrm{C}, 1 \mathrm{~s}^{-1}$; (c) $950{ }^{\circ} \mathrm{C}, 0.1 \mathrm{~s}^{-1}$; (d) $1000{ }^{\circ} \mathrm{C}, 0.01 \mathrm{~s}^{-1}$; (e) $1000{ }^{\circ} \mathrm{C}, 0.001 \mathrm{~s}^{-1}$; and (f) $1050{ }^{\circ} \mathrm{C}, 0.001 \mathrm{~s}^{-1}$.

\subsection{Peak Strain and Critical Strain}

According to the flow curves obtained from hot-working, the peak strain $\left(\varepsilon_{\mathfrak{p}}\right)$ of each flow curve is as listed in Table 1. It was observed that the $\varepsilon_{\mathrm{p}}$ gradually declined with the increment deformation temperature of at a given strain rate.

In previous work, the value of deformation activation energy $(Q)$ was calculated to be $207.7 \mathrm{~kJ} / \mathrm{mol}$. The constitutive equation of the $47 \mathrm{Zr}-45 \mathrm{Ti}-5 \mathrm{Al}-3 \mathrm{~V}$ alloy has been established according to the hyperbolic-sine Arrhenius-type equation as follows [11]:

$$
\dot{\varepsilon}=6.7 \times 10^{8}\left[\sinh \left(\alpha \sigma_{p}\right)\right]^{3.09} \exp \left(-\frac{207700}{R T}\right)
$$

Hence, the relationship between the $\varepsilon_{\mathrm{p}}$ and Zener-Hollomon parameter $\left(Z=\dot{\varepsilon} \exp \left(\frac{Q}{R T}\right)\right)$ can be characterized, as shown in Figure 5. The relation between the $\varepsilon_{\mathrm{p}}$ and $Z$ can be written as the following formula [25-28]:

$$
\varepsilon_{p}=8.61 \times 10^{-5} Z^{0.39}
$$

Generally, when the strain reaches a critical strain $\left(\varepsilon_{\mathrm{c}}\right)$ during hot-working, the DRX can occur due to the driving of dislocation accumulation and entanglement [29]. The critical strain $\left(\varepsilon_{\mathrm{c}}\right)$ is corresponding to the start point of DRX, which can be achieved by a turning point $(\partial(\partial \theta / \partial \sigma) / \partial \sigma=0)$ gained from the curve of strain hardening rate $(\theta)$ corresponding to the true stress $(\sigma)[30,31]$. In this present study, the values of $\varepsilon_{\mathrm{c}}$ at various hot-working 
parameters were listed in Table 1 . The relation between $\varepsilon_{\mathrm{c}}$ and $\varepsilon_{\mathrm{p}}$ can be expressed by the following [32]:

$$
\varepsilon_{\mathrm{c}}=\beta \varepsilon_{\mathrm{p}}
$$

where the value of $\beta$ (material constant) can be achieved to be 0.67 by the data in Figure 6 . By integrating Equation (2) with Equation (3), the $\varepsilon_{c}$ can be written as follows:

$$
\varepsilon_{\mathrm{c}}=5.77 \times 10^{-5} Z^{0.39}
$$

\begin{tabular}{|c|c|c|c|c|c|c|c|c|}
\hline \multirow{2}{*}{ Temperature } & \multicolumn{4}{|c|}{$\varepsilon_{\mathrm{p}}$} & \multicolumn{4}{|c|}{$\varepsilon_{\mathrm{c}}$} \\
\hline & $1 s^{-1}$ & $0.1 s^{-1}$ & $0.01 \mathrm{~s}^{-1}$ & $0.001 s^{-1}$ & $1 s^{-1}$ & $0.1 \mathrm{~s}^{-1}$ & $0.01 \mathrm{~s}^{-1}$ & $0.001 \mathrm{~s}^{-1}$ \\
\hline $850^{\circ} \mathrm{C}$ & 0.38 & 0.21 & 0.12 & 0.07 & - & - & - & - \\
\hline $900^{\circ} \mathrm{C}$ & 0.34 & 0.14 & 0.11 & 0.055 & - & - & 0.07 & 0.038 \\
\hline $950^{\circ} \mathrm{C}$ & 0.26 & 0.1 & 0.083 & 0.025 & 0.17 & 0.06 & 0.05 & 0.018 \\
\hline $1000^{\circ} \mathrm{C}$ & 0.17 & 0.08 & 0.03 & 0.012 & 0.13 & 0.05 & 0.018 & 0.006 \\
\hline $1050^{\circ} \mathrm{C}$ & 0.13 & 0.05 & 0.02 & 0.01 & 0.09 & 0.03 & 0.01 & 0.004 \\
\hline
\end{tabular}

Table 1. The values of $\varepsilon_{\mathrm{p}}$ and $\varepsilon_{\mathrm{c}}$ under various hot-working conditions.

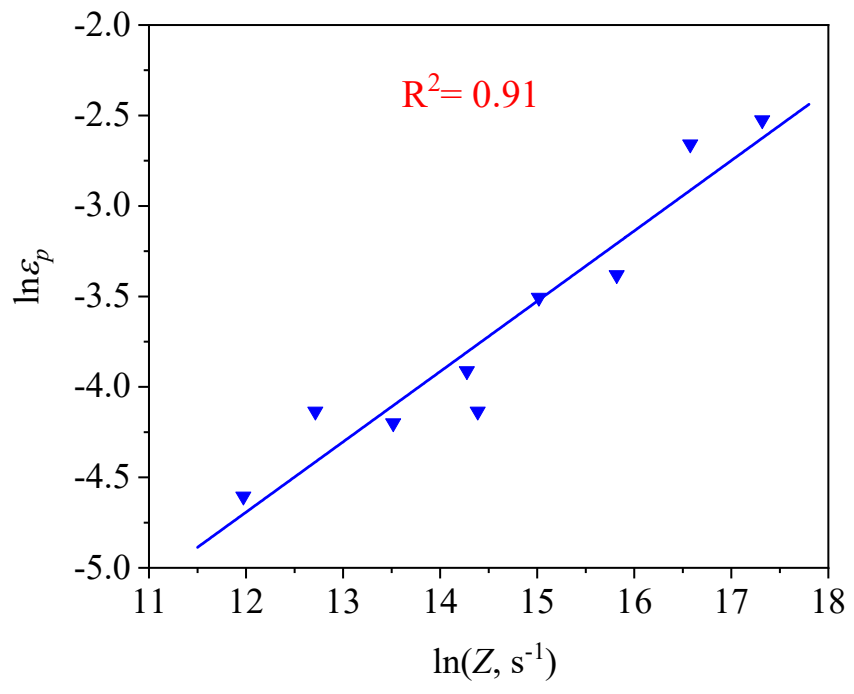

Figure 5. Relationship between the $\ln Z$ and $\ln \varepsilon_{p}$.

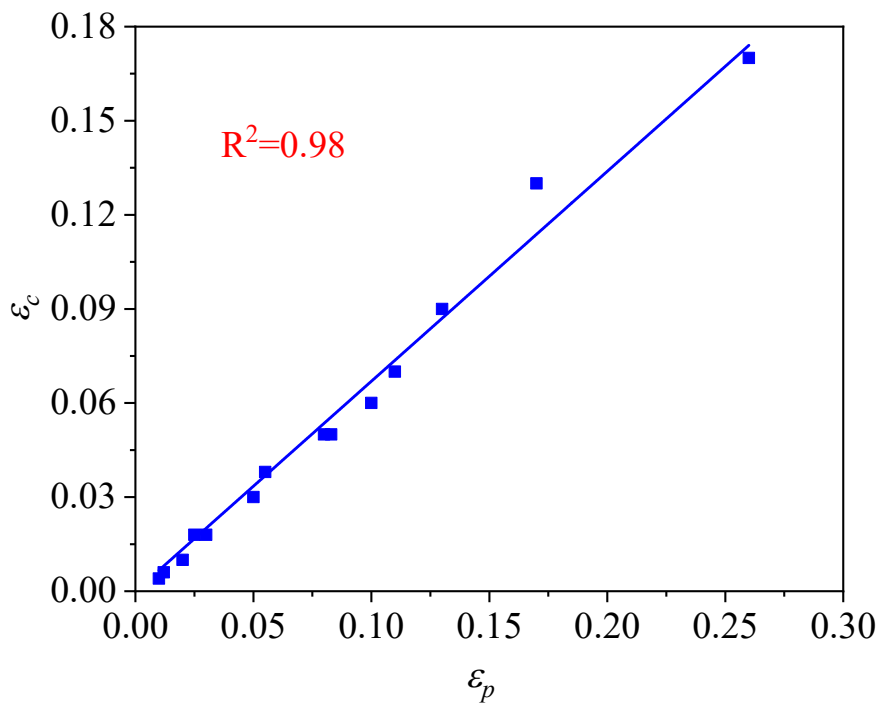

Figure 6. Relationship between the $\varepsilon_{\mathrm{c}}$ and $\varepsilon_{\mathrm{p}}$. 


\subsection{Kinetics Model of DRX}

The DRX behavior consisted of nucleation and growth during hot-working. For the discontinuous recrystallization mechanism, the nucleus of DRX grains generally formed in the grain boundaries, and then grew toward the interior of the grains with a high density nearby the grain boundaries. The $X_{D R X}$ of DRX grains was significantly affected by the hot-working parameters, which is expressed by using the JMAK equation [32,33]:

$$
X_{D R X}=1-\exp \left[-k \times\left(\frac{\varepsilon-\varepsilon_{c}}{\varepsilon_{\mathrm{p}}}\right)^{n}\right]
$$

where $k$ and $n$ represent the Avrami material constants. In previous work, the measuring of the $\mathrm{X}_{D R X}$ was usually obtained by OM and the Electron Backscatter Diffraction (EBSD) technique [33]; however, those methods require considerable calculations and are expensive to carry out. In order to solve the above problems, $X_{D R X}$ is extensively computed based on the relationship between $X_{D R X}$ and $\sigma$ in the process of hot-working, which can be expressed as follows [34,35]:

$$
X_{D R X}=\frac{\sigma_{p}-\sigma}{\sigma_{p}-\sigma_{s s}}
$$

where $\sigma_{p}$ and $\sigma_{s s}$ are on behalf of the peak stress and the steady flow stress of the flow curve, respectively. To calculate the values of $k$ and $n$ in Equation (5), we take the natural logarithm on both sides of Equation (5), as written in Equation (7):

$$
\ln \left[-\ln \left(1-X_{D R X}\right)\right]=\ln k+n \ln \left[\left(\varepsilon-\varepsilon_{c}\right) / \varepsilon_{p}\right]
$$

The $k$ and $n$ (average values) can be calculated as 0.0021 and 1.88 by the data in Figure 7, respectively. Hence, the kinetic model of $D R X$ was expressed as follows:

$$
X_{D R X}=1-\exp \left[-0.0021 \times\left(\frac{\varepsilon-\varepsilon_{c}}{\varepsilon_{p}}\right)^{1.88}\right]
$$

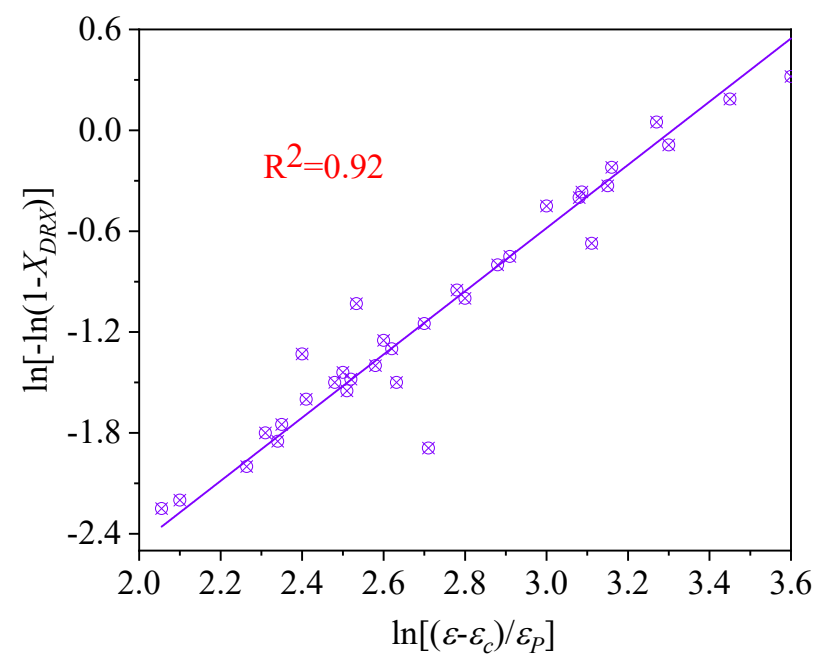

Figure 7. Relationship between $\ln \left[-\ln \left(1-X_{D R X}\right)\right]$ and $\operatorname{In}\left[\left(\varepsilon-\varepsilon_{c}\right) / \varepsilon_{p}\right]$.

The $X_{D R X}-\varepsilon$ curves were obtained from the DRX kinetics model of $47 \mathrm{Zr}-45 \mathrm{Ti}-5 \mathrm{Al}-3 \mathrm{~V}$ alloy at various deformation conditions, as shown in Figure 8. So, as to further analyze the growth behavior of DRX grains, the $d_{D R X}$ as a function of $Z$ parameter was characterized by the follow [35]:

$$
d_{D R X}=C Z^{m_{1}}
$$


where the $C$ and $m_{1}$ are constants. The Equation (9) can be rewritten as the form of Equation (10):

$$
\ln d_{D R X}=\ln C+m_{1} \ln Z
$$

The variation on the $d_{D R X}$ with hot-working parameters was depicted in Figure 9. The material constants were calculated as $C=2565.73$ and $m_{1}=-0.25$, respectively. Therefore, the connection between the $d_{D R X}$ and the $Z$ parameter can be showed as follows:

$$
d_{D R X}=2565.73 Z^{-0.25}
$$
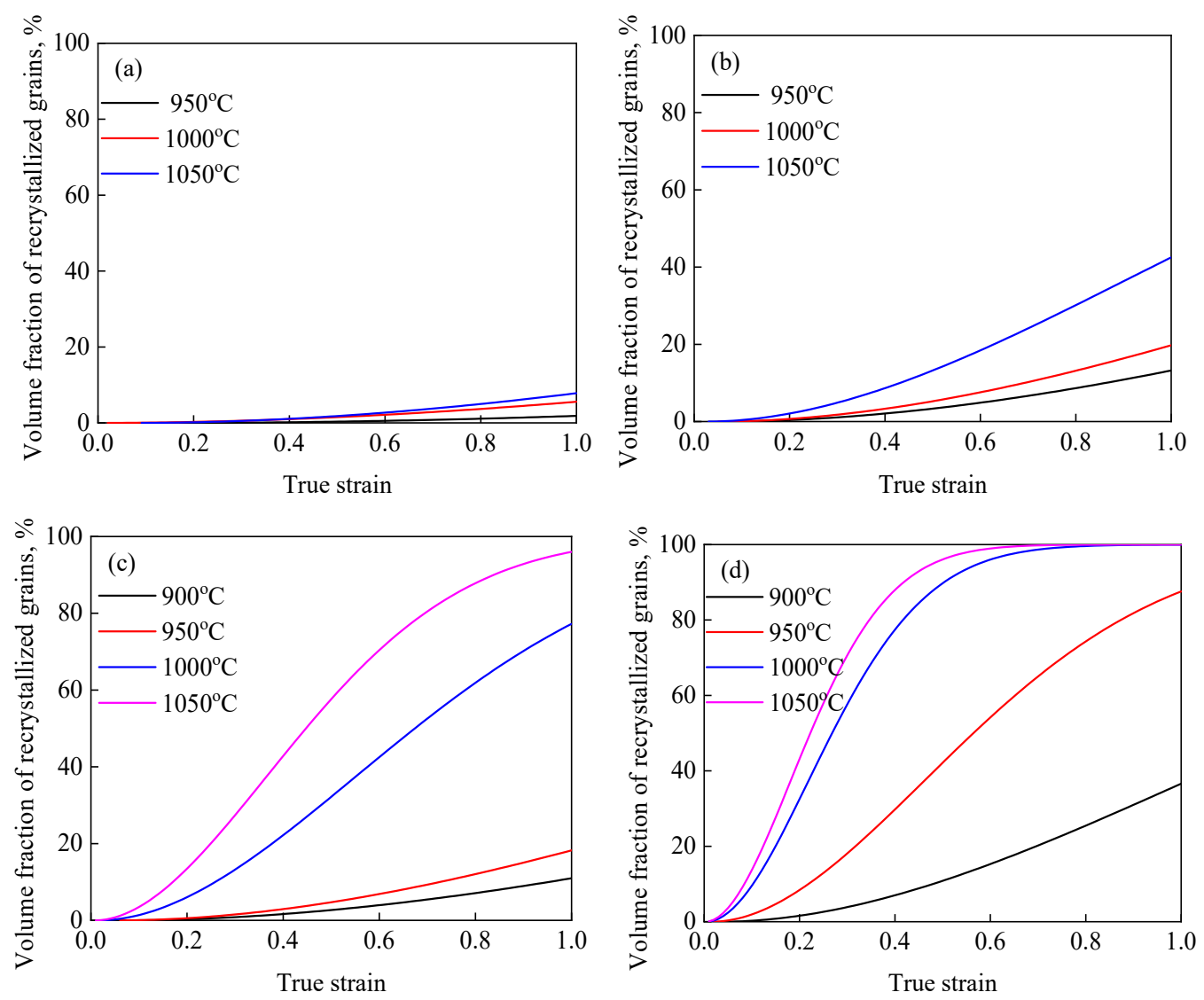

Figure 8. Variation in the $X_{D R X}$ with true strain at different temperatures of (a) $1 \mathrm{~s}^{-1},(\mathbf{b}) 0.1 \mathrm{~s}^{-1}$, (c) $0.01 \mathrm{~s}^{-1}$ and (d) $0.001 \mathrm{~s}^{-1}$.

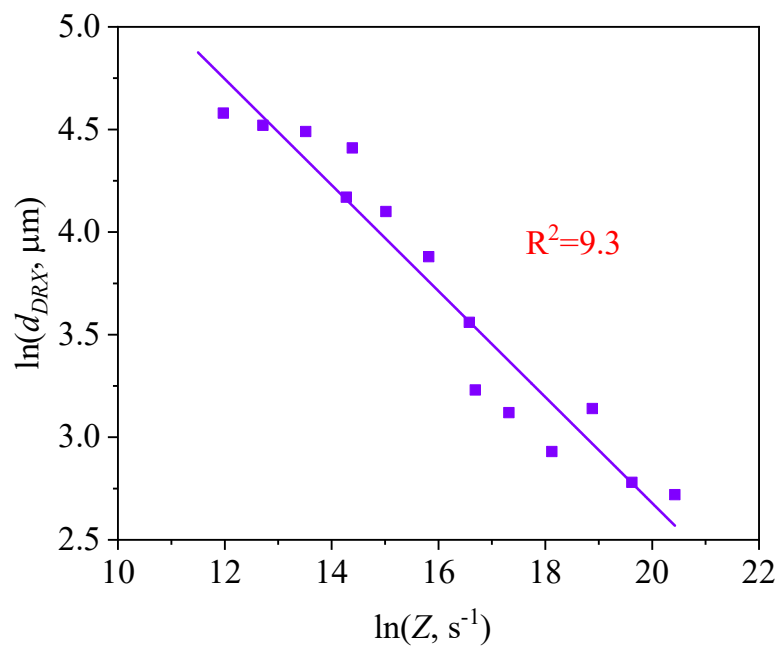

Figure 9. Relationship between $\ln d_{D R X}$ and $\ln Z$. 


\subsection{FEM of DRX Behavior}

Based on the DRX kinetic equation established above, the isothermal forging process was simulated by the DEFORM-3D software (Scientific Forming Technologies Corporation, Columbus, $\mathrm{OH}, \mathrm{USA}$ ) During the process of isothermal forging simulation, the elastic deformation can be usually ignored. Therefore, the workpiece was treated as an object with plasticity, while the tools were treated as an object with rigidity. For improving the efficiency of FEM calculation and increasing the accuracy of the simulation results, the FE model was established by symmetrical half cylinder. The sample for FEM was segmented in terms of tetrahedral meshes. The numbers of the meshes and the nodes were set to 26,538 and 4726 , respectively. The top die was set as movable, while the bottom die was fixed. The coefficient of the friction was set to be 0.3 [33]. For the keeping consistency between experimental and the simulation results, the temperature of all items in the model was set to be consistent with the experimental temperature during the process of FEM. Figure 10 shows the sketch map of effective stress for FEM at the true strain of 0.7. It is seen that the deformation region is mainly divided into three different regions, according to the degree of the deformation, as marked in Figure 10. A heavy deformation took place in region I, while only a slight deformation was observed in region II. Usually, the region II is defined as the free deformation area. It is noted that non-deformation was presented in region III, namely "dead zone" $[33,34]$. This indicates that the plastic deformation of the samples is uneven.

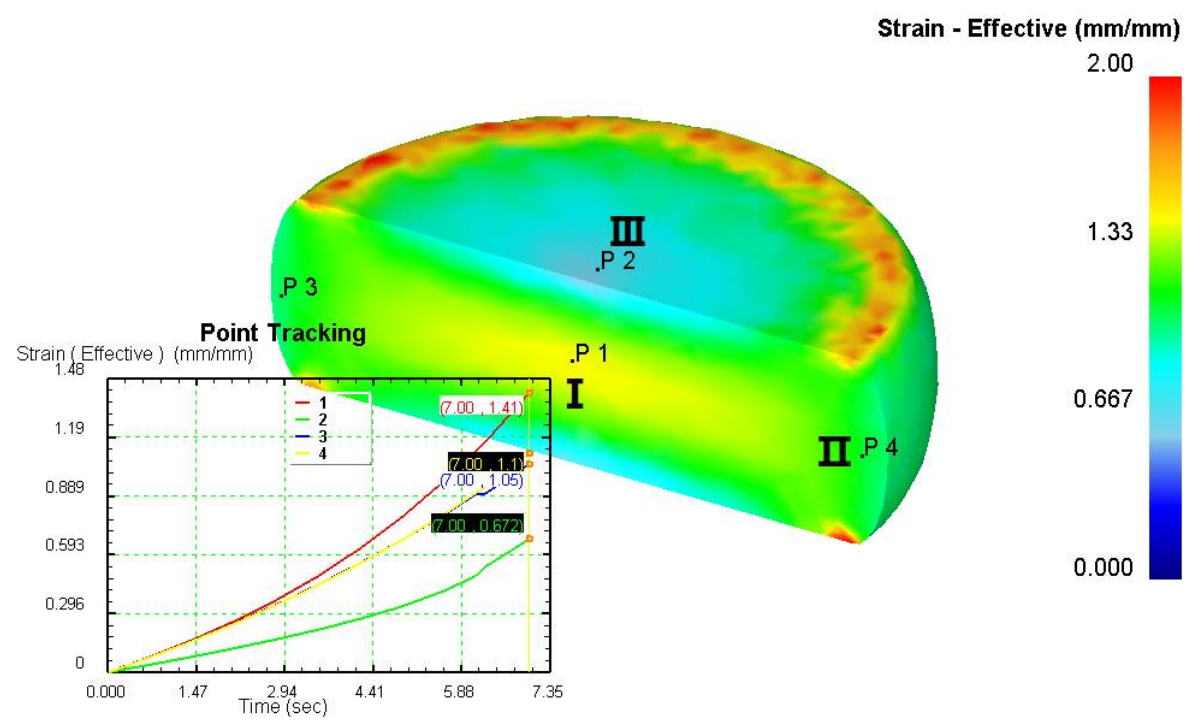

Figure 10. Diagram of deformation area.

Table 2 displays the distribution cloud maps of the $d_{D R X}$ for $47 \mathrm{Zr}-45 \mathrm{Ti}-5 \mathrm{Al}-3 \mathrm{~V}$ alloys. It is worth noting that the $d_{D R X}$ distribution is uneven in different regions, due to the non-uniformity of deformation in the compression process. Under low $T$ and high $\dot{\varepsilon}$ conditions, only a few DRX grains with small size formed in region $I$, while dynamic recrystallization cannot occur in region III, where the size of grains keeps the original grain size. With the augment of $T$ and the drop of $\dot{\varepsilon}$, the size of DRX grains gradually increased. When the deformation condition is $1050{ }^{\circ} \mathrm{C} / 0.001 \mathrm{~s}^{-1}$, the size of DRX grains increased to approximately $128 \mu \mathrm{m}$. It is worth noting that the size of DRX grains in region III is higher than that in region II. Table 3 depicts the distribution cloud maps of the $X_{D R X}$ deformed at the true strain of 0.7. It can be observed from Table 3 that the $X_{D R X}$ is obviously low under low $T$ and high $\dot{\varepsilon}$ conditions. With the augment of $T$ and the drop of $\dot{\varepsilon}$, the $X_{D R X}$ gradually increased. It is also important to note that the distribution of the $X_{D R X}$ is also non-uniform in different regions during hot-working. Regions with a large degree of deformation have higher deformation storage energy, thereby promoting the nucleation of DRX [36-40]. The $X_{D R X}$ in region I is higher than that in regions II and III. 
Table 2. The distribution of $d_{D R X}$ for $47 \mathrm{Zr}-45 \mathrm{Ti}-5 \mathrm{Al}-3 \mathrm{~V}$ alloys deformed under various hot-working conditions at the true strain of 0.7 .

\begin{tabular}{|c|c|c|c|c|c|}
\hline \multirow{2}{*}{ Strain Rate/s ${ }^{-1}$} & \multicolumn{4}{|c|}{ Temperature $/{ }^{\circ} \mathrm{C}$} & \multirow{2}{*}{$d_{D R X}, \mu \mathrm{m}$} \\
\hline & 900 & 950 & 1000 & 1050 & \\
\hline 0.001 & & & & & 130 \\
\hline 0.01 & & & & & 86.7 \\
\hline 0.1 & & & & & 43.3 \\
\hline 1 & & & & & \\
\hline
\end{tabular}

Table 3. The distribution of $X_{D R X}$ for $47 \mathrm{Zr}-45 \mathrm{Ti}-5 \mathrm{Al}-3 \mathrm{~V}$ alloys deformed under various hot-working conditions at the true strain of 0.7 .

Strain Rate/s ${ }^{-1}$

Figures 11 and 12 illustrate a difference between the experimental and FEM results of $d_{D R X}$ and $X_{D R X}$, respectively. A good consistency is observed between experimental and the simulation results. The change trends of $d_{D R X}$ and $X_{D R X}$ for the experimental and the simulation results are consistent. According to References [33,40], the correlation between the experimental and the simulation results was characterized by the correlation coefficient $\left(R^{2}\right)$ and the average absolute relative error $(\Delta)$ value. It is seen from Figures 13 and 14 that the experimental results keep a linear relationship with the FEM results. The value of $R^{2}$ was 0.95 and 0.99 for the $d_{D R X}$ and $X_{D R X}$, respectively. It is generally believed that DRX does not occur in the area where the $X_{D R X}$ percentage is less than $5 \%$; thus, the $\Delta$ value of the $d_{D R X}$ and $X_{D R X}$ for DRX grains was computed to be, respectively, $15.7 \%$ and $8.78 \%$. This suggests that the DRX behavior of $47 \mathrm{Zr}-45 \mathrm{Ti}-5 \mathrm{Al}-3 \mathrm{~V}$ alloy can be described well by the established kinetic equations that are embedded in the DEFORM-3D software. 


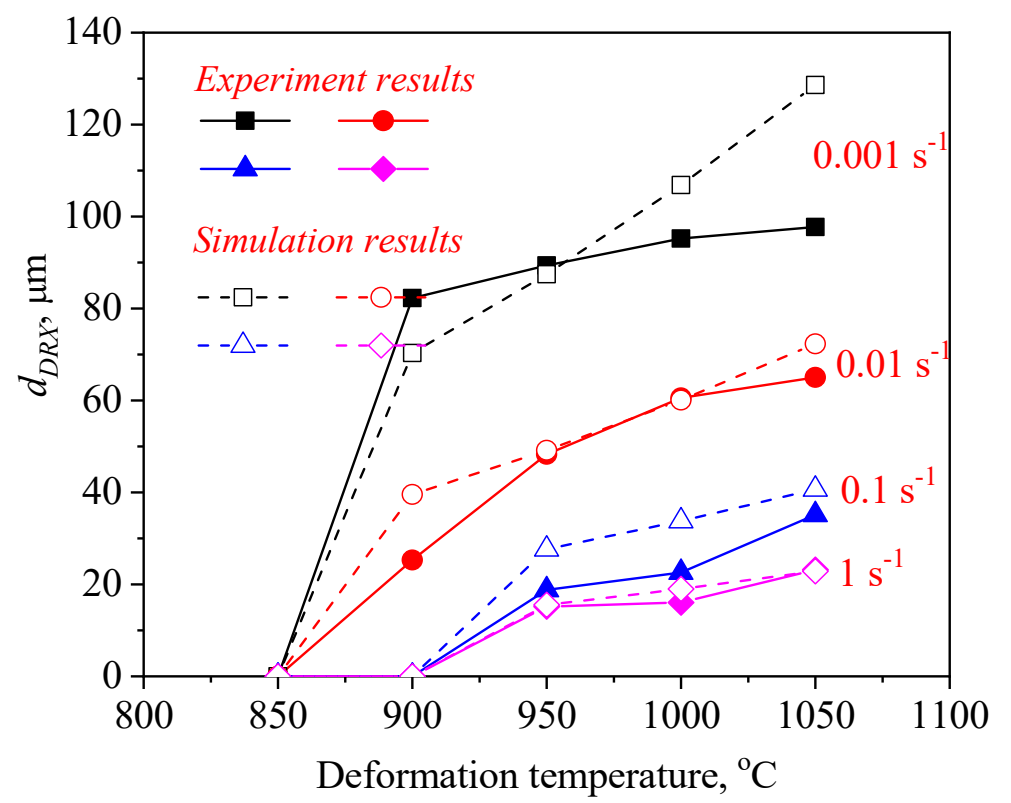

Figure 11. A comparison between the experimental and FE results of the grain size of recrystallized grains $\left(d_{D R X}\right)$.

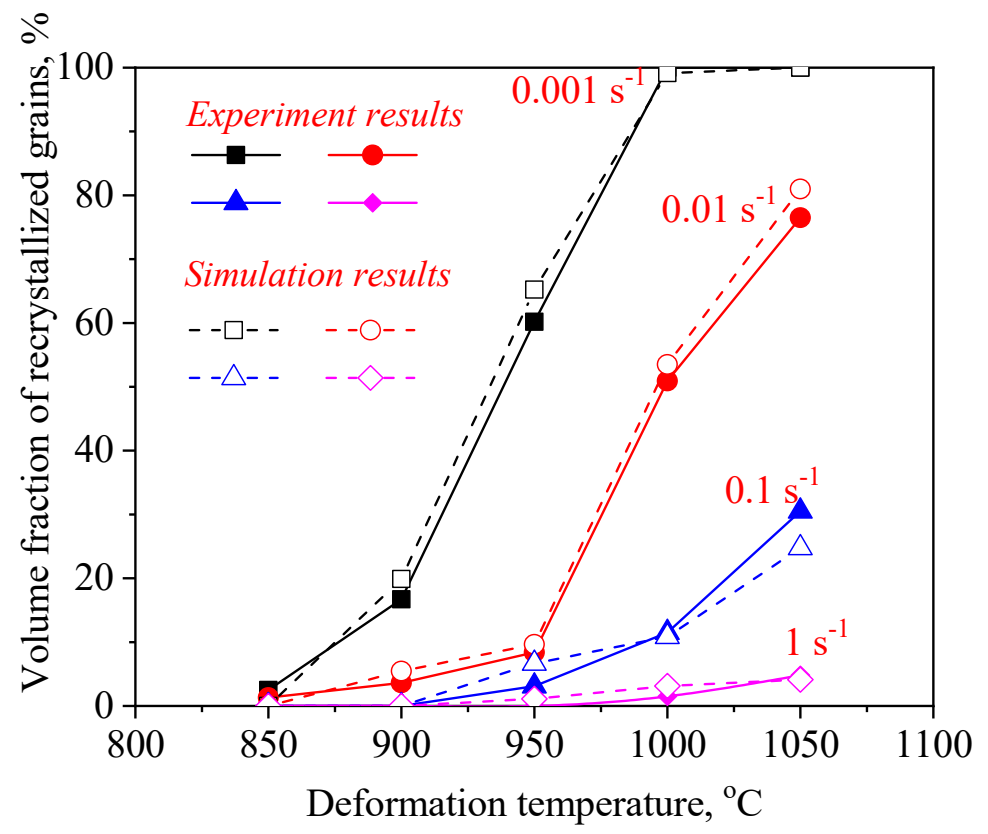

Figure 12. A comparison between the experimental and FE simulation results of the volume fraction of DRX $\left(X_{D R X}\right)$. 


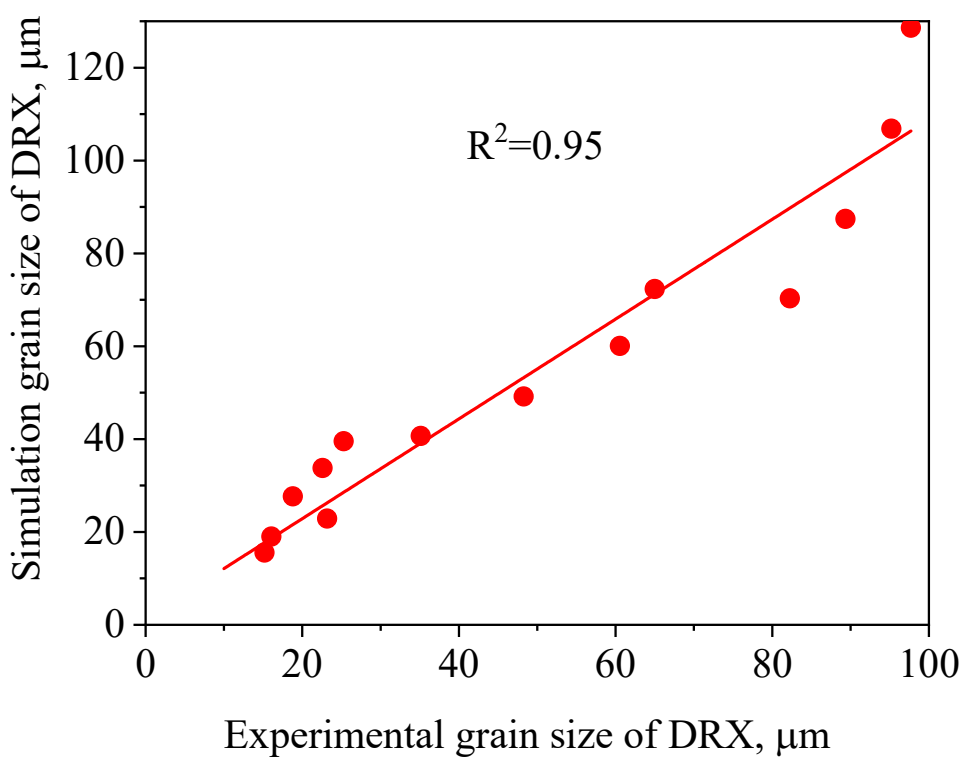

Figure 13. Correlation between the FEM and experimental grain size of DRX for 47Zr-45Ti-5Al-3V alloys after hot deformation.

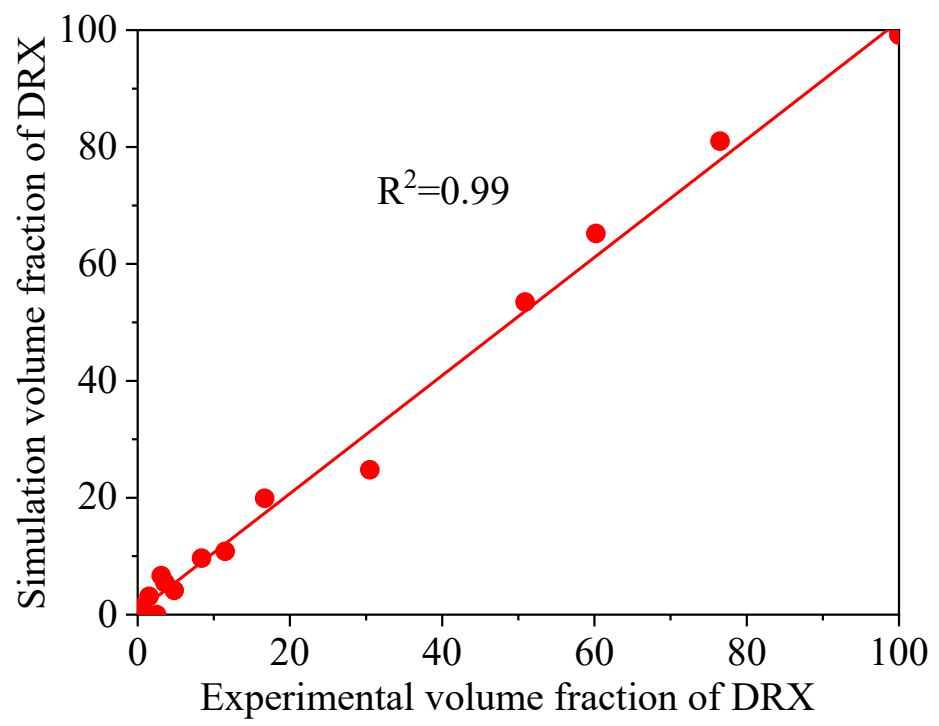

Figure 14. Correlation between the FEM and experimental volume fraction of DRX for 47Zr-45Ti5Al-3V alloys after hot deformation.

\subsection{CA of DRX Behavior}

The CA method is a mathematical algorithm used to describe the evolution of a complex system in discrete space-time. Usually, the CA model consists of four basic elements: cell space, neighbor type, boundary conditions and cell state. The cell orientation is set to a random number from 1 to 180 , and the cell transformation rule is "Moore neighbor". From the viewpoint of dislocation density, the plastic deformation of metals is attributed to dislocation slip and climbing. In the process of hot-working, the dislocation density in the matrix increases with the increase of strain, and the evolution of the microstructure during the hot deformation is always accompanied by the change of dislocation density. In the CA model, the dislocation model can be described as follows [22,41]:

$$
\sigma=\alpha \mu b \sqrt{\bar{\rho}}
$$




$$
\frac{d \rho}{d \varepsilon}=k_{1} \sqrt{\rho}-k_{2} \sqrt{\rho}
$$

where the $\alpha$ is $0.5 ; \rho$ and $\bar{\rho}$ represent the dislocation density and average dislocation density respectively; $b$ represents the Burger's vector; $\mu$ represents the shear modulus; and $k_{1}$ and $k_{2}$ represent work-hardening and dynamic-softening coefficients, respectively. There is no $\rho$ gradient inside a single grain of alloy during the hot-working. The $\bar{\rho}$ during the CA simulation can be expressed as follows [42]:

$$
\bar{\rho}=\frac{1}{N_{0}} \sum_{i, j}^{i=A, j=B} \rho_{i, j}
$$

where A and B respectively represent the number of cells in the $i$ and $j$ directions; $N_{0}$ represents the total number of cells; and $\rho_{i, j}$ represents the dislocation density of the cell at coordinates $(i, j)$. During the hot-working process, as the dislocation density reaches the critical dislocation density $\left(\rho_{c}\right)$, the DRX grains begin to nucleate. In addition, the formation of DRX grains reduces the $\rho$ of the alloy, and a new round of DRX occurs as the amount of deformation further increases. The nucleation rate $(\dot{n})$ is linearly related to the $\dot{\varepsilon}[22,42]$ :

$$
\dot{n}=C \dot{\varepsilon}^{\alpha}
$$

where $C$ and $\alpha$ usually take 200 and 0.9 , respectively.

Based on the initial microstructure of the solution-treated alloy, the initial solid solution structure was simulated by the CA simulation, as shown in Figure $1 \mathrm{~b}$. The experimental and predicted microstructures by CA after hot-working were displayed in Figure 15. The CA simulation results show that the evolution of DRX grains is strongly correlated with hot processing parameters. Figures 16 and 17 reveal that the experimental results keep a linear relationship with the CA results. The $\Delta$ value of the $d_{D R X}$ and $X_{D R X}$ for DRX grains was computed to be respectively $6.32 \%$ and $9.3 \%$. In general, CA simulation has more accurate results than FEM simulation. However, FEM can more intuitively simulate the overall change of the alloy during the whole process of hot compression. The combination of FEM and CA simulation can more effectively predict the macro and micro evolution of DRX for 47Zr-45Ti-5Al-3V alloy. 

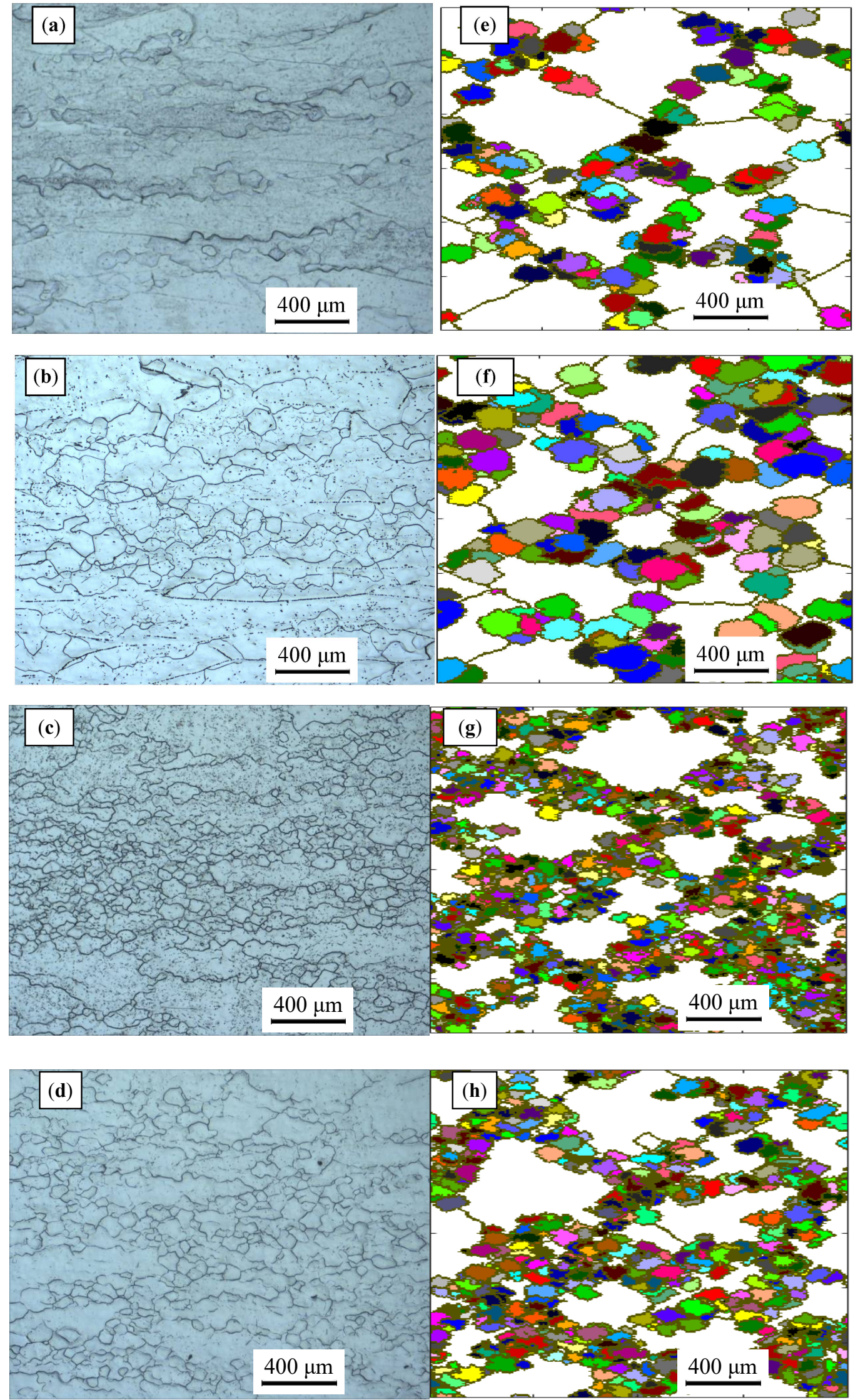

Figure 15. Microstructure of the $47 \mathrm{Zr}-45 \mathrm{Ti}-5 \mathrm{Al}-3 \mathrm{~V}$ alloys after hot-working and CA simulation result: $(\mathbf{a}, \mathbf{e}) 900^{\circ} \mathrm{C} / 10^{-3} \mathrm{~s}^{-1}$, $(\mathbf{b}, \mathbf{f}) 950{ }^{\circ} \mathrm{C} / 10^{-3} \mathrm{~s}^{-1},(\mathbf{c}, \mathbf{g}) 1000{ }^{\circ} \mathrm{C} / 10^{-2} \mathrm{~s}^{-1}$ and $(\mathbf{d}, \mathbf{h}) 1050^{\circ} \mathrm{C} / 10^{-2} \mathrm{~s}^{-1}$. 


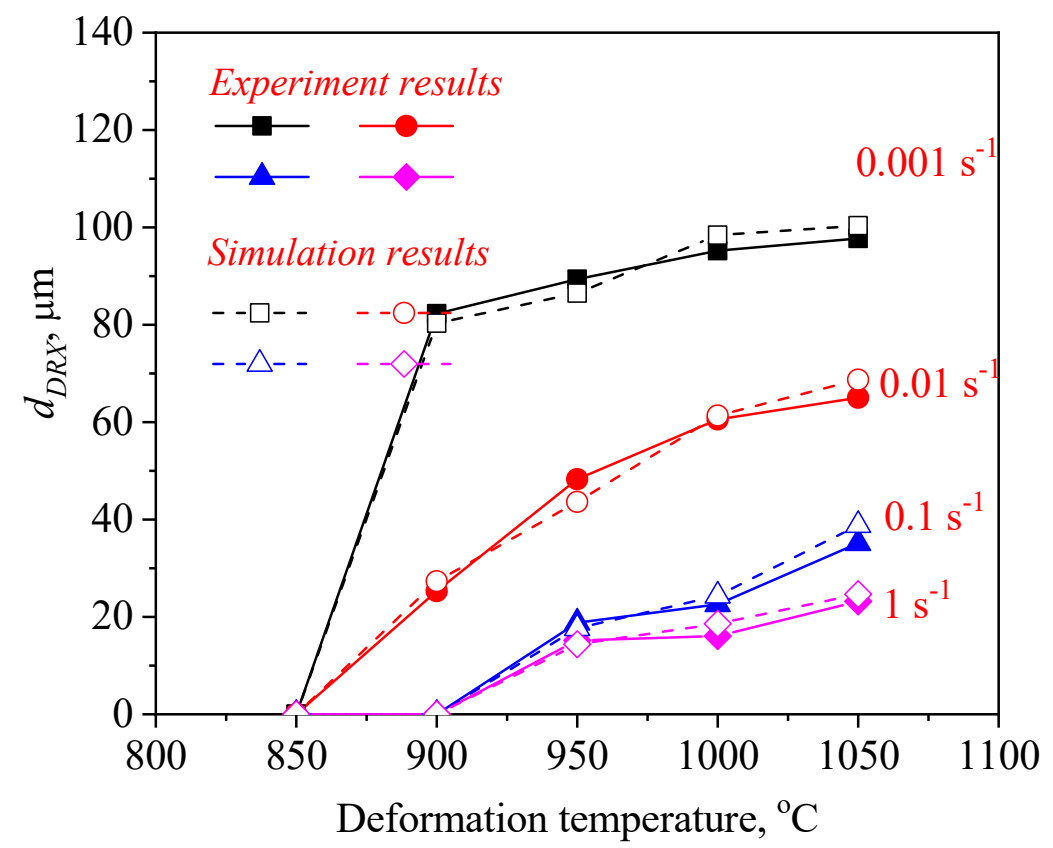

Figure 16. A comparison between the experimental and CA results of the $d_{D R X}$.

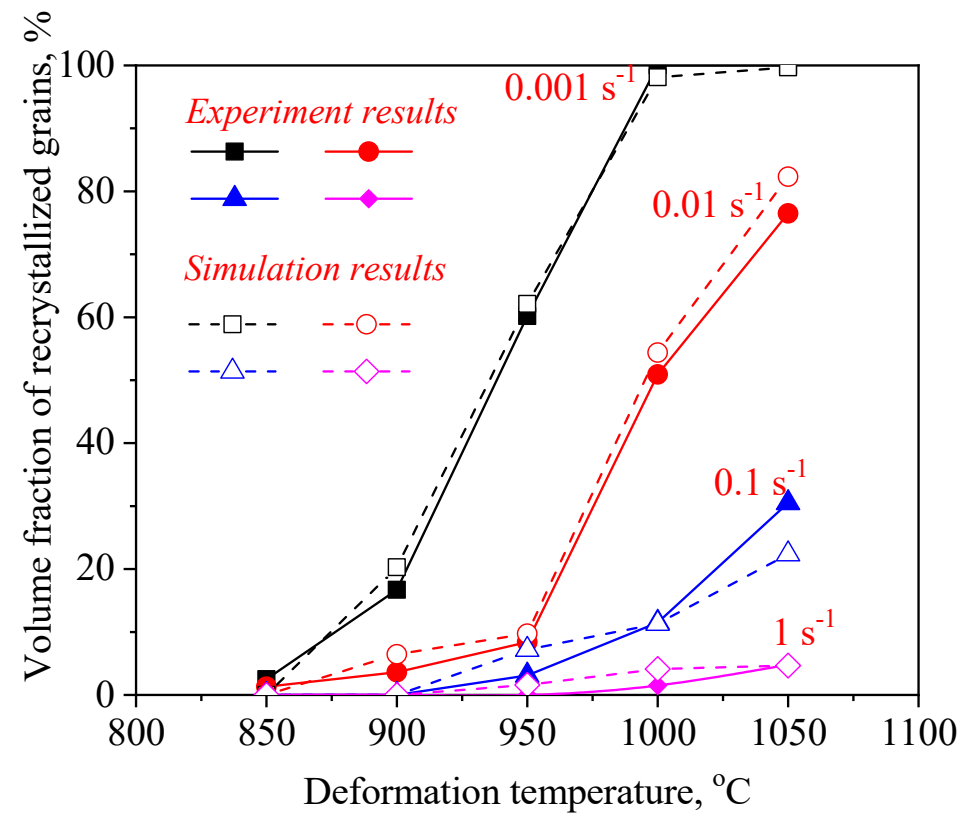

Figure 17. A comparison between the experimental and CA simulation results of the $X_{D R X}$.

\section{Conclusions}

The DRX behavior of the 47Zr-45Ti-5Al-3V alloy was investigated by using a CA-FE simulation. The main conclusion obtained can be drawn as follows:

(1) In this present study, the main softening mechanism of $47 \mathrm{Zr}-45 \mathrm{Ti}-5 \mathrm{Al}-3 \mathrm{~V}$ alloy was regarded as DRX. The results revealed that the deformation $T$ and $\dot{\varepsilon}$ have a strong effect on the DRX behavior of $47 \mathrm{Zr}-45 \mathrm{Ti}-5 \mathrm{Al}-3 \mathrm{~V}$ alloy. The $\mathrm{X}_{D R X}$ and $d_{D R X}$ of DRX grains increased with rising $T$ and decreasing $\dot{\varepsilon}$. 
(2) Based on the hot-working test, the $\mathrm{X}_{D R X}$ and $d_{D R X}$ model of DRX were established, which can be written as the following formula:

$$
\left\{\begin{array}{c}
X_{D R X}=1-\exp \left[-0.0021 \times\left(\frac{\varepsilon-\varepsilon_{c}}{\varepsilon_{\mathrm{p}}}\right)^{1.88}\right] \\
d_{D R X}=2565.73 Z^{-0.25}
\end{array}\right\}
$$

(3) The value of $R^{2}$ was, respectively, 0.95 and 0.99 for the $d_{D R X}$ and $X_{D R X}$ between the experimental and FEM results, while the average $\Delta$ value for the $d_{D R X}$ and $X_{D R X}$ was, respectively, $15.7 \%$ and $8.78 \%$, which indicated that the FEM results of $X_{D R X}$ and $d_{D R X}$ are in great line with the experimental results.

(4) The $\Delta$ value of the $d_{D R X}$ and $X_{D R X}$ for DRX grains is respectively computed in the process of CA simulation. The $\Delta$ value of the $d_{D R X}$ and $X_{D R X}$ was, respectively, $6.32 \%$ and $9.3 \%$ for CA simulation, which indicated that CA simulation has more accurate results than FEM.

Author Contributions: Conceptualization, S.X. and Y.T.; methodology, Y.T., Y.Y. and W.Z.; software, F.Z. and Q.Y.; validation, Y.T.; formal analysis, W.Z.; investigation, W.Z. and Y.T.; resources, S.X. and Y.T.; data curation, W.Z.; writing —original draft preparation, W.Z.; writing—review and editing, Y.T.; visualization, Y.T. and W.Z.; supervision, S.X. and Y.T.; project administration, Y.T. and Q.Y.; funding acquisition, Y.T. and Y.Y. All authors have read and agreed to the published version of the manuscript.

Funding: This work was supported by the NSFC (Grant no. 51804087), Basic research program of Guizhou Province (Grant no. [2019]1091), Youth Science and Technology Talent Growth Project of Guizhou Education Bureau (No. [2018]107), Breeding programs of Guizhou University (Grant no. [2019]16) and Open program of Key Laboratory of Metastable Materials Science and Technology (Grant no. 202001).

Institutional Review Board Statement: Not applicable.

Informed Consent Statement: Not applicable.

Data Availability Statement: Data sharing is not applicable to this article.

Conflicts of Interest: The authors declare no conflict of interest.

\section{References}

1. Ma, B.; Qi, X.; Li, R.; Zhang, R.; Shang, H. The Zr alloying effect on microstructure evolution and mechanical properties of nanostructured Al-Zr alloyed films. J. Alloys Compd. 2020, 858, 157707.

2. Rodriguez, P. Irradiation effects in zirconium alloy core components of PHWRs. In Proceedings of the Symposium on Zirconium Alloys for Reactor Components, Bombay, India, 12-13 December 1991; Bhabha Atomic Research Centre: Bombay, India, 1992; pp. 46-95.

3. Tao, B.R.; Qiu, R.S.; Liu, Y.S.; Tan, X.N.; Liu, Q. FCC phase transformation of Zr alloy during air cooling and aging. J. Nucl. Mater. 2021, 551, 152989. [CrossRef]

4. Qu, L.; Yang, Z.N.; Zhang, F.C.; Zhang, M.; Zhang, X.Y.; Liu, R.P. Effect of deformation and heat treatment on the microstructure and mechanical properties of $\beta$-Zr40Ti5Al4V alloy. J. Alloys Compd. 2014, 612, 80-89. [CrossRef]

5. Tan, Y.B.; Ji, L.Y.; Liu, W.C.; Xiang, S.; Liang, Y.L. Effect of hot deformation on $\alpha \rightarrow \beta$ phase transformation in 47Zr-45Ti-5Al-3V alloy. Trans. Nonferrous Met. Soc. 2018, 28, 1947-1957. [CrossRef]

6. Liang, S.X.; Yin, L.X.; Liu, X.Y.; Jing, R.; Zhou, Y.K.; Ma, M.Z.; Liu, R.P. Effects of annealing treatments on microstructure and mechanical properties of the Zr-45Ti-5Al-3V alloy. Mater. Sci. Eng. A 2013, 582, 374-378. [CrossRef]

7. Tan, Y.B.; Yang, L.H.; Duan, J.L.; Ji, L.Y.; Liu, W.C. Studies on the kinetics of $\beta \rightarrow \alpha$ phase transformation in 47Zr-45Ti-5Al-3V alloy under isothermal conditions by X-ray diffraction. Mater. Charact. 2016, 112, 98-104. [CrossRef]

8. Tan, Y.B.; Yang, L.H.; Tian, C.; Liu, W.C.; Liu, R.P.; Zhang, X.Y. Processing maps for hot working of 47Zr-45Ti-5Al-3V alloy. Mater. Sci. Eng. A 2014, 597, 171-177. [CrossRef]

9. Tan, Y.B.; Yang, L.H.; Duan, J.L.; Liu, W.C.; Zhang, J.W.; Liu, R.P. Effect of initial grain size on the hot deformation behavior of 47Zr-45Ti-5Al-3V alloy. J. Nucl. Mater. 2014, 454, 413-420. [CrossRef]

10. Tan, Y.B.; Ji, L.Y.; Duan, J.L.; Liu, W.C.; Zhang, J.W.; Liu, R.P. A study on the hot deformation behavior of 47Zr-45Ti-5Al-3V alloy with initial lamellar $\alpha$ structure. Metall. Mater. Trans. A 2016, 12, 5974-5984. [CrossRef] 
11. Tan, Y.B.; Yang, L.H.; Tian, C.; Liu, R.P.; Zhang, X.Y.; Liu, W.C. Hot deformation behavior of ZrTiAlV alloy with a coarse grain structure in the $\beta$ phase field. Mater. Sci. Eng. A 2013, 577, 218-224. [CrossRef]

12. Sass, S.L. The Phase in a Zr-25 at.\% Ti Alloy. Acta Metall. 1969, 17, 813-820. [CrossRef]

13. Chakravartty, J.K.; Dey, G.K.; Banerjee, S.; Prasad, Y.V.R.K. Characterization of Hot Deformation Behaviour of Zr-2.5Nb-0.5Cu Using Processing Maps. J. Nucl. Mater. 1995, 218, 247-255. [CrossRef]

14. Kutty, T.R.G.; Ravi, K.; Ganguly, C. Studies on Hot Hardness of Zr and Its Alloys for Nuclear Reactors. J. Nucl. Mater. 1999, 265, 91-99. [CrossRef]

15. Nikulina, A.V.; Markelov, V.A.; Peregud, M.M.; Voevodin, V.N.; Panchenko, V.L.; Kobylyansky, G.P. Irradiation-Induced Microstructural Changes in Zr-1\%Sn-1\%Nb-0.4\%Fe. J. Nucl. Mater. 1996, 238, 205-210. [CrossRef]

16. Irani, M.; Joun, M. Determination of JMAK dynamic recrystallization parameters through FEM optimization techniques. Comput. Mater. Sci. 2018, 142, 178-184. [CrossRef]

17. Ji, H.C.; Cai, Z.M.; Pei, W.C.; Huang, X.M.; Lu, Y.H. DRX behavior and microstructure evolution of 33Cr23Ni8Mn3N: Experiment and finite element simulation. J. Mater. Res. Technol. 2020, 9, 4340-4355. [CrossRef]

18. Wu, H.; Xu, W.C.; Wang, S.B.; Yang, Z.Z.; Chen, Y.; Teng, B.G.; Shan, D.B.; Guo, B. A cellular automaton coupled FEA model for hot deformation behavior of AZ61 magnesium alloys. J. Alloys Compd. 2020, 816, 152562. [CrossRef]

19. Nithin, B.; Pandey, P.; Chattopadhyay, K.; Phanikumar, G. Influence of thermomechanical processing parameters on microstructural evolution of a gamma-prime strengthened cobalt based superalloy during high temperature deformation. Mater. Sci. Eng. A 2020, 791, 139498.

20. Geng, P.H.; Qin, G.L.; Zhou, J.; Li, T.Y.; Ma, N.S. Characterization of microstructures and hot-compressive behavior of GH4169 superalloy by kinetics analysis and simulation. J. Mater. Process. Technol. 2020, 288, 116879. [CrossRef]

21. Zhang, T.; Li, L.; Lu, S.H.; Gong, H.; Wu, Y.X. Comparisons of Different Models on Dynamic Recrystallization of Plate during Asymmetrical Shear Rolling. Materials 2018, 11, 151. [CrossRef]

22. Li, H.W.; Sun, X.X.; Yang, H. A three-dimensional cellular automata-crystal plasticity finite element model for predicting the multiscale interaction among heterogeneous deformation, DRX microstructural evolution and mechanical responses in titanium alloys. Int. J. Plast. 2016, 87, 154-180. [CrossRef]

23. Xie, B.C.; Zhang, B.Y.; Ning, Y.Q.; Fu, M.W. Mechanisms of DRX nucleation with grain boundary bulging and subgrain rotation during the hot working of nickel-based superalloys with columnar grains. J. Alloys Compd. 2019, 786, 636-647. [CrossRef]

24. Quan, G.Z.; Shi, R.J.; Zhao, J.; Liu, Q.; Xiong, W.; Qiu, H.M. Modeling of dynamic recrystallization volume fraction evolution for AlCu4SiMg alloy and its application in FEM. Trans. Nonferr. Met. Soc. 2019, 29, 1138-1151. [CrossRef]

25. Liu, J.; Cui, Z.; Ruan, L. A new kinetics model of dynamic recrystallization for magnesium alloy AZ31B. Mater. Sci. Eng. A 2011, 529, 300-310. [CrossRef]

26. Chen, L.; Zhang, Y.J.; Li, F.; Liu, X.G.; Guo, B.F.; Jin, M. Modeling of dynamic recrystallization behavior of $21 \mathrm{Cr}-11 \mathrm{Ni}-\mathrm{N}-\mathrm{RE}$ lean austenitic heat-resistant steel during hot deformation. Mater. Sci. Eng. A 2016, 663, 141-150. [CrossRef]

27. Zhou, S.S.; Deng, K.K.; Li, J.C.; Nie, K.B.; Xu, F.J.; Zhou, H.F.; Fan, J.F. Hot deformation behavior and workability characteristics of bimodal size SiCp/AZ91 magnesium matrix composite with processing map. Mater. Des. 2014, 64, 177-184. [CrossRef]

28. Wu, H.; Liu, M.X.; Wang, Y.; Huang, Z.Q.; Tan, G.; Yang, L. Experimental study and numerical simulation of dynamic recrystallization for a FGH96 superalloy during isothermal compression. J. Mater. Res. Technol. 2020, 9, 5090-5104. [CrossRef]

29. Li, X.C.; Duan, L.L.; Li, J.W.; Wu, X.C. Experimental study and numerical simulation of dynamic recrystallization behavior of a micro-alloyed plastic mold steel. Mater. Des. 2015, 66, 309-320. [CrossRef]

30. Buffa, G.; Ducato, A.; Fratini, L. FEM based prediction of phase transformations during friction stir welding of Ti6Al4V titanium alloy. Mater. Sci. Eng. A 2013, 581, 56-65. [CrossRef]

31. Liu, J.; Wang, X.H.; Liu, J.T.; Liu, Y.F.; Li, H.Y.; Wang, C. Hot deformation and dynamic recrystallization behavior of Cu-3Ti-3Ni0.5Si alloy. J. Alloys Compd. 2019, 782, 224-234. [CrossRef]

32. Wan, Z.P.; Sun, Y.; Hu, L.X.; Yu, H. Experimental study and numerical simulation of dynamic recrystallization behavior of TiAl-based alloy. Mater. Des. 2017, 122, 11-20. [CrossRef]

33. Zhang, W.W.; Yang, Q.Y.; Tan, Y.B.; Ma, M.; Xiang, S.; Zhao, F. Simulation and Experimental Study of Dynamical Recrystallization Kinetics of TB8 Titanium Alloys. Materials 2020, 13, 4429. [CrossRef]

34. Ji, G.L.; Li, F.G.; Li, Q.H.; Li, H.Q.; Li, Z. Research on the dynamic recrystallization kinetics of Aermet100 steel. Mater. Sci. Eng. A 2010, 527, 2350-2355. [CrossRef]

35. Wang, S.L.; Zhang, M.X.; Wu, H.C.; Yang, B. Study on the Dynamic Recrystallization Model and Mechanism of Nuclear Grade 316LN Austenitic Stainless Steel. Mater. Charact. 2016, 118, 92-101. [CrossRef]

36. Zhang, C.S.; Wang, C.X.; Guo, R.; Zhao, G.Q.; Chen, L.; Sun, W.C.; Wang, X.B. Investigation of Dynamic Recrystallization and Modeling of Microstructure Evolution of an Al-Mg-Si Aluminum Alloy during High-Temperature Deformation. J. Alloys Compd. 2019, 773, 59-70. [CrossRef]

37. Wen, D.X.; Lin, Y.C.; Zhou, Y. A New Dynamic Recrystallization Kinetics Model for A Nb Containing Ni-Fe-Cr-Base Superalloy Considering Influences of Initial delta Phase. Vacuum 2017, 141, 316-327. [CrossRef]

38. Tan, K.; Li, J.; Guan, Z.J.; Yang, J.B.; Shu, J.X. The Identification of Dynamic Recrystallization and Constitutive Modeling during Hot Deformation of Ti55511 Titanium Alloy. Mater. Des. 2015, 84, 204-211. [CrossRef] 
39. Zhao, Z.L.; Min, X.N.; Xu, W.X.; Cao, L.C.; Zang, G.; Song, X.Y.; Li, H. Dynamic Recrystallization Models of AerMet100 Ultrahighstrength Steel During Thermo-mechanical Processing. Rare Met. Mater. Eng. 2020, 49, 3285-3293.

40. Lin, Y.C.; Chen, M.S. Numerical Simulation and Experimental Verification of Microstructure Evolution in a Three-Dimensional Hot Upsetting Process. J. Mater. Process. Technol. 2009, 209, 4578-4583. [CrossRef]

41. Cao, Z.H.; Sun, Y.; Zhou, C.; Wan, Z.P.; Yang, W.H.; Ren, L.L.; Hu, L.X. Cellular Automaton Simulation of Dynamic Recrystallization Behavior in V-10Cr-5Ti Alloy under Hot Deformation Conditions. Trans. Nonferrous Met. Soc. China $2019,29,98-111$. [CrossRef]

42. Cheng, F.; Cui, Z.S.; Liu, J.A.; Cheng, W.; Chen, S.J. Mesoscale Simulation of the Hightemperature Austenitizing and Dynamic Recrystallization by Coupling a Cellular Automaton with a Topology Deformation Technique. Mater. Sci. Eng. A 2010, 527, 5539-5549. [CrossRef] 